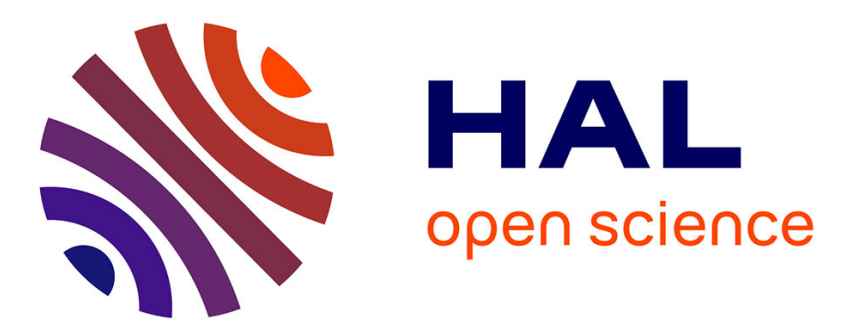

\title{
A review of greenhouse gas emission liabilities as the value of renewable energy for mitigating lawsuits for climate change related damages
}

\author{
Negin Heidari, Joshua Pearce
}

\section{To cite this version:}

Negin Heidari, Joshua Pearce. A review of greenhouse gas emission liabilities as the value of renewable energy for mitigating lawsuits for climate change related damages. Renewable and Sustainable Energy Reviews, 2016, 55, pp.899-908. 10.1016/j.rser.2015.11.025 . hal-02113574

\section{HAL Id: hal-02113574 \\ https://hal.science/hal-02113574}

Submitted on 29 Apr 2019

HAL is a multi-disciplinary open access archive for the deposit and dissemination of scientific research documents, whether they are published or not. The documents may come from teaching and research institutions in France or abroad, or from public or private research centers.
L'archive ouverte pluridisciplinaire HAL, est destinée au dépôt et à la diffusion de documents scientifiques de niveau recherche, publiés ou non, émanant des établissements d'enseignement et de recherche français ou étrangers, des laboratoires publics ou privés. 
Preprint: Negin Heidari \& Joshua M. Pearce. A Review of Greenhouse Gas Emission Liabilities as the Value of Renewable Energy for Mitigating Lawsuits for Climate Change Related Damages. Renewable and Sustainable Energy Reviews 55C (2016) pp. 899-908. DOI: 10.1016/j.rser.2015.11.025

\title{
A Review of Greenhouse Gas Emission Liabilities as the Value of Renewable Energy for Mitigating Lawsuits for Climate Change Related Damages
}

Negin Heidari ${ }^{1}$ and Joshua M. Pearce ${ }^{1,2, *}$

1. Department of Electrical \& Computer Engineering, Michigan Technological University, MI, USA

2. Department of Materials Science \& Engineering, Michigan Technological University, MI, USA

* corresponding author: 601 M\&M Building, 1400 Townsend Drive, Houghton, MI 49931-1295

906-487-1466 pearce@mtu.edu

\begin{abstract}
Anthropogenic global climate change has large and mounting negative economic impacts. Companies and nations responsible for greenhouse gas (GHG) emissions are thus acquiring considerable potential liabilities. If litigation becomes widespread, renewable energy technologies (RETs) potentially offer emitters reduced liability for climate change. This benefit has been ignored because of the lack of knowledge of potential liabilities. To overcome this information deficit, this paper reviews recent literature on the potential for climate change litigation and methods to quantify liability for climate change. Next, the top ten emitters in the U.S. are identified and their potential liability is quantified using standard GHG emission costs. Potential liabilities are explored in depth with a single case study company comparing the results of the fractional liability from only natural disasters within the U.S. for a single year to a sensitivity of the future costs of carbon emissions from other sources of emission-related liability. Then classes of potential climate change litigants are identified and their capacity to bring such lawsuits are evaluated. The results show that the net income available to shareholders of large companies could see a significant reduction from the emissions liability related to only natural disasters in the U.S. from a single coal-fired power plant. Finally, a rough estimate of the economic risk associated with future scenarios and existing organized international potential litigants is quantified. The results show that potential liability for climate change for the Alliance of Small Island States is over $\$ 570$ trillion. It is concluded that as emitters begin to be held liable for damages resulting from GHG emissions resulting in climate change, a high value for liability mitigation would provide additional powerful incentives for deployment of renewable energy technologies.
\end{abstract}

Keywords: renewable energy; climate change; litigation; liability; global warming; ; greenhouse gas emissions

\section{Introduction}

Renewable energy technologies (RETs) have well established benefits including: i) improving environmental sustainability [1-3], ii) improving public health [4-6], iii) creating jobs [6-9] and iv) financial benefits [10-12]. For example, the average price of completed solar photovoltaic (PV) systems have dropped 33\% since 2011 [13], and the cost of electricity generated from wind also dropped more than $43 \%$ in the past four years [14]. As the economic costs of RETs have decreased they are now competitive with traditional electricity sources in many regions [10-12]. Perhaps one of RETs greatest benefits, however, is the value they bring for mitigation of greenhouse gas (GHG) emissions and the concomitant climate change [1519]. Both global GHG emissions [20-22] and global atmospheric carbon dioxide $\left(\mathrm{CO}_{2}\right)$ concentrations are are increasing rapidly $[23,24]$. The resultant climate change is well established with a high confidence as are the negative impacts on natural and socio-economic systems $[25,26]$ including: i) higher temperatures and heat waves that result in thousands of deaths from hyperthermia [27-29], ii) crop failures [30,31] that aggravate global hunger [32-34], iii) power outages [35,36], iv) rising sea levels which causes the low-lying coastal areas to submerge gradually [37,38], v) erosion of shorelines [37,38], vi) increased risk of flooding [39], and saltwater intrusion [37,40], vii) strong storms which causes more damage to coastal environment, increased risk of floods, [41-44], viii) droughts, [45] and ix) fire [43,46,47]. These negative externalities have been shown to be due to human activities with the confidence level of $95 \%$ (primarily combustion of fossil fuels, which are the dominant cause of global warming from 1951 to 2010)[48,49].

Emission trading has been considered as a solution to climate change in order to limit greenhouse gas emissions [50-53]. Unfortunately, it has some disadvantages including relying on a complicated system [54], carbon price uncertainty [55], and encouraging industries that are the most dependent on coal and oil to maintain the status quo because the permits have been historically inexpensive [56]. Thus, at the present time, emissions trading as a method of mitigating climate change has essentially failed [57-59], so another method is needed. 
Preprint: Negin Heidari \& Joshua M. Pearce. A Review of Greenhouse Gas Emission Liabilities as the Value of Renewable Energy for Mitigating Lawsuits for Climate Change Related Damages. Renewable and Sustainable Energy Reviews 55C (2016) pp. 899-908. DOI: 10.1016/j.rser.2015.11.025

A method gaining traction to bring these negative externalities into the market is the use of litigation, which provides a different path to motivate reducing corporate actions resulting in climate change [60-69]. If such GHG emission litigation becomes widespread, then the one of the core benefits of RETs for emitters would be a reduction in the liability for climate change. This economic benefit is currently often ignored because of the lack of knowledge of the potential liabilities. To provide the necessary data, this paper first reviews recent literature on the potential for climate change litigation and the seven methods to quantify liability for climate change. Then, this paper provides a formulation is developed to estimate the liability for GHG emitters considering i ) pollution factor (which is a fraction of emissions produced by each major polluter over the overall emissions), ii) probability of human contribution to natural disasters, and iii) estimated cost of disasters. Next, the top ten emitters in the U.S. are identified and their potential liability is quantified using standard carbon costs and this method. Potential liabilities are explored in depth in this paper with a single company comparing the results of the fractional liability from only natural disasters within the U.S. for a single year to a sensitivity of the future costs of carbon emissions from other sources of emission-related liability. Finally, potential climate change victims (potential litigants) are identified and their capacity to bring such lawsuits are evaluated. The results are discussed and conclusions are drawn about the potential value for RETs to reduce GHG emission liability.

\section{Background}

GHG emissions liability is created from present emissions, but can also extend into the past. For example, Farber [62] argued that not only American's ancestors, but also people who are living in U.S. currently are responsible for past emissions resulting in climate change due to the profit they have had from uncontrolled GHG emissions. Similarly he argued that a moral responsibility exists for Americans to limit their emissions to prevent causing damage to other people (specifically those living in poor nations) [62]. Similarly, Kilinsky showed the victims that are losing their land, culture, and themselves due to climate change, should be put in top priority for compensation [66]. Public awareness of climate change will shift to what solutions are available for the climate change problem from questioning reality of climate change when the urgency of emission reduction becomes validated by courts and credible institutions [66]. Already good reasons may exist for liability imposition on governments for disastrous events [65]. It is believed that tort law could be applied to climate change and tort based lawsuits are possible from a legal point of view [65]. Although it has been pointed out that tort law is not the only method that can be utilized against climate change, it could be an important part [67]. For climate change litigants, public nuisance law has been considered to be a promising cause of action, and litigants can sue potential defendants due to their interference with public rights under public nuisance law [65]. Other studies have concluded that emitters should be responsible for the impacts of their excess emissions and should be obliged to buy long term insurance in order to cover their share of climate change costs for future for minimizing risks in case of insolvencies [68].

Because of these potential litigation-related losses, it is believed that a some corporations' welfare is affected significantly by GHG emissions, and as such lawyers working on behalf of corporations need to be well educated about risks that would be imposed due to climate change in order to warn clients subsequently [64]. For example, gas-producing companies can be significantly affected by controlling GHG emissions [63]. Thus, it has been pointed out that corporations need to scrutinize whether to disclose their GHG emissions to the SEC in order to reduce the risks, because litigation could arise and corporations would face a negative shareholder response due to such disclosures [63]. It is shown that the price of remedial measures substitutes for current resources and that it would be a mistake to delay a compensation because a rejected compensation most likely will be rejected permanently; therefore, instead of waiting for the damage to occur, the ex ante measures of damages are preferred for compensation schemes [61]. Finally, because of climate change, risk of floods would increase in many areas causing insurance premium rises, which cause the house prices to fall and some of this loss could be blamed on GHG emissions[69]. Although in such cases it can not yet be said with a high level confidence level that human activities have contributed to a particular weather event, in order to compute a figure as a basis for compensation, the concept of averaging over possibilities can be used which can show how greenhouse gases may have increased the risk of weather events [69]. Solidifying these calculations could result in a plethora of lawsuits from climate change aggravated events causing billions of dollars of damages (e.g. storms, flooding, tornadoes, droughts, crop losses, storm surges, etc.) 
Preprint: Negin Heidari \& Joshua M. Pearce. A Review of Greenhouse Gas Emission Liabilities as the Value of Renewable Energy for Mitigating Lawsuits for Climate Change Related Damages. Renewable and Sustainable Energy Reviews 55C (2016) pp. 899-908. DOI: 10.1016/j.rser.2015.11.025

\section{Methods}

\subsection{Nomenclature:}

C: Carbon price [US\$/ton of $\mathrm{CO}_{2}$ ]

$\mathrm{d}_{\mathrm{i}}(\mathrm{t})$ : Cost of ith disaster

$D_{x}(t)$ : Liability of a single defendant in year $t$

$\mathrm{E}$ : Emissions [tons of $\mathrm{CO}_{2}$ ]

$\mathrm{E}_{\mathrm{CR}}$ : Responsibility of consumer [tons of $\mathrm{CO}_{2}$ ]

$\mathrm{E}_{\text {embodied: }}$ : Producer's emissions [tons of $\mathrm{CO}_{2}$ ]

$\mathrm{E}_{\text {ISR: }}$ Responsibility of intermediate system [tons of $\mathrm{CO}_{2}$ ]

$\mathrm{Ep}_{\mathrm{p}}$ : Producer's emissions [tons of $\mathrm{CO}_{2}$ ]

$\mathrm{E}_{\mathrm{PR}}$ : Producer responsibility [tons of $\mathrm{CO}_{2}$ ]

$\mathrm{E}_{\text {use }}$ : Consumer's emissions [tons of $\mathrm{CO}_{2}$ ]

$E_{X}$ : Emissions in year $t$ of a single defendant [tons of $\mathrm{CO}_{2}$ ]

$E_{\text {region: }}$ Emissions in year $t$ of the region of interest [tons of $\mathrm{CO}_{2}$ ]

F:Ecological footprint [acre]

$\mathrm{F}_{\mathrm{C}}$ : Ecological footprint of producer [acre]

$\mathrm{F}_{\mathrm{e}}$ : Responsibility sharing factor

$\mathrm{F}_{\mathrm{is}}$ : Ecological footprint of intermediate system [acre]

$\mathrm{F}_{\mathrm{p}}$ : Ecological footprint of producer [acre]

$\mathrm{L}_{\text {CA-C: }}$ Consumer's liability [US\$]

L CA-IS $_{\text {: }}$ Liability of intermediate system [US\$]

L A-P: Producer's liability [US\$]

$\mathrm{L}_{\mathrm{CR}}$ : Consumer's liability [US\$]

$\mathrm{L}_{\mathrm{EF}}$ : Consumer's liability [US\$]

$\mathrm{L}_{\mathrm{GC}}$ : Consumer's liability [US\$]

$\mathrm{L}_{\mathrm{GIS}}$ : Liability of intermediate system [US\$]

$\mathrm{L}_{\mathrm{GP}}$ : Producer's liability [US\$]

Lpp: Polluter's liability [US\$]

LPR $_{\text {P }}$ Producer's liability [US\$]

LsR: Shared responsibility [US\$]

$\mathrm{N}$ : Number of disasters

$P_{x}(t)$ : Pollution factor of a single defendant in year $t$

$\mathrm{R}_{\mathrm{F}}$ : Footprint to emission conversion [tons of $\mathrm{CO}_{2} / \mathrm{acre}$ ]

$\mathrm{T}(\mathrm{t})$ : Estimated total cost of natural disasters in year $\mathrm{t}$

Z: probability of the human emissions contribution to natural disasters [percent]

\subsection{Methods of Assigning Liability}

This study first identifies the methods used to quantify the global warming liability including:

1) The polluter's pay theory developed by Reimund, which considers a monetary damage per ton of $\mathrm{CO}_{2}[70]$. Reimund used US\$50/ton, included transaction costs and based the analysis on emissions of power plants from 1992.

2) A shared responsibility approach using an input-output analysis, in which responsibility is shared between producers and consumers developed by Lenzen et al. [71]. Normally, input-output analysis models the flows in an economy. Leontief Inverse matrices obtained from input output tables capture the infinite regression of transactions between industries and discovers the indirect economic requirements of industries. To simply this process, here only the way of allocating responsibility from Lenzen et al. was used.

3) Producer responsibility approach assumes that the full burden of responsibility is borne by producers [71].

4) Consumer responsibility approach assumes that the full burden of responsibility is borne by consumers [71]. 
Preprint: Negin Heidari \& Joshua M. Pearce. A Review of Greenhouse Gas Emission Liabilities as the Value of Renewable Energy for Mitigating Lawsuits for Climate Change Related Damages. Renewable and Sustainable Energy Reviews 55C (2016) pp. 899-908. DOI: 10.1016/j.rser.2015.11.025

5) The carbon emission added approach [72], which uses a process that divides responsibility into components so producers and consumers are defined for each part, and the GHG emission is assigned to phases of the process in proportion to the included GHG emission needed along the chain.

6) The geographical approach [72], which only considers emissions that are directly involved in parts of a nation within the borders of the country and the contribution to emission is evaluated without including fuel combustion that is indirectly related to the system such as transportation.

7) The ecological footprint methodology that translates ecological impact into surface area [73] and is based on the actual consumption of goods by inhabitants of a country [72].

The seven methods for determining liability are summarized in Table 1.

Table 1. Potential Methods of Assigning Climate Change Liability

Methods

Liability Equations in US\$

1. The polluter's pay theory $\quad \mathrm{L}_{\mathrm{pp}}=\left(\sum E\right) \times C$

2. A shared responsibility approach using an input- $L_{S R}=F \times R_{F} \times F_{e} \times C$ output analysis

3. Producer responsibility approach $\quad L_{P R}=\left(\sum E_{P}\right) \times C$

4. Consumer responsibility approach $\quad L_{C R}=\left(\sum E_{\text {embodied }}+E_{\text {use }}\right) \times C$

5. The carbon emission added approach $\quad E_{P R}=E_{p} E_{I S R}=E_{p}+E_{i s} E_{C R}=E_{p}+E_{i s}+E_{c}$

$L_{C A-P}=E_{P R} /\left(E_{P R}+E_{I S R}+E_{C R}\right) \times 100 \times C$

$L_{C A-I S}=E_{I S R} /\left(E_{P R}+E_{I S R}+E_{C R}\right) \times 100 \times C$

$L_{C A-C}=E_{C R} /\left(E_{P R}+E_{I S R}+E_{C R}\right) \times 100 \times C$

6. The geographical approach

$L_{G P}=E_{p} \times C$

$L_{G I S}=E_{i s} \times C$

$L_{G C}=E_{c} \times C$

7. The ecological footprint methodology $\quad L_{E F}=\left(F_{p}+F_{i s}+F_{c}\right) \times R_{F} \times C$

Then the economic victims (and potential litigants) are identified and their capacity to bring such a lawsuit are evaluated using the following formula as a measure of potential damages (D): 
Preprint: Negin Heidari \& Joshua M. Pearce. A Review of Greenhouse Gas Emission Liabilities as the Value of Renewable Energy for Mitigating Lawsuits for Climate Change Related Damages. Renewable and Sustainable Energy Reviews 55C (2016) pp. 899-908. DOI: 10.1016/j.rser.2015.11.025

$$
D_{x}(t)=P_{x}(t) \times Z \times T(t)=\frac{E_{x}}{E_{\text {Region }}} \times Z \times \sum_{i=1}^{N} d_{i}(t)
$$

where pollution factor $(\mathrm{P})$ of major polluters is the ratio of the emissions in year $\mathrm{t}$ from a single defendant $(\mathrm{x})$ over the emissions of the region of interest (e.g. country ) in year t, $\mathrm{Z}$ is the probability in percent of the human emissions contribution to natural disasters. It should be noted here that the value of $\mathrm{Z}$ for a given disaster is complex as it demands determining the anthropogenic responsibility. Finally, $\mathrm{T}$ is the estimated total cost of natural disasters made up of the sum of costs of $\mathrm{N}$ disasters (d) in year t [74]. Thus the potential damages quantified by equation 1 is the liability based on the total cost of natural disasters multiplied by the fraction that can be attributed to humans and the fraction attributable to an individual emitter as illustrated in Figure 1. Although the share of causality could be based on the aggregate human emissions up to time t, here as a case study only a single year (2012) of emissions [75] and costs will be evaluated as a demonstration.

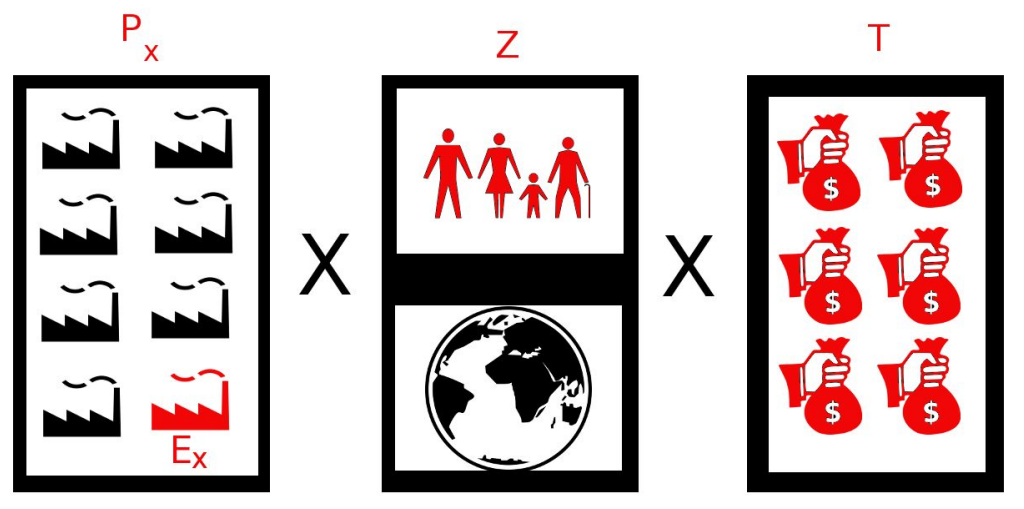

Figure 1. Schematic approach of liability from greenhouse gas emissions.

$\mathrm{R}_{\mathrm{F}}$ is a conversion factor which is the land area required to sequester 1 ton of $\mathrm{CO}_{2}$ and it is equal to 0.19 acre per ton of $\mathrm{CO}_{2}$ [76]. Although, internal carbon prices used in different companies in the United States ranges from US\$6 (Microsoft) to US\$80 (Exxon Mobil and Encana) [77], US\$80/ton is used here for calculating the liability as a baseline, acknowledging that the potential future liability could be much greater per ton of GHG emissions. Next, the top emitters are identified in the U.S. and their potential liability is quantified using methods shown in Table 1 for which data is available $(1,2,3,4$ and 7$)$ as shown in Table 2. 
Preprint: Negin Heidari \& Joshua M. Pearce. A Review of Greenhouse Gas Emission Liabilities as the Value of Renewable Energy for Mitigating Lawsuits for Climate Change Related Damages. Renewable and Sustainable Energy Reviews 55C (2016) pp. 899-908. DOI: 10.1016/j.rser.2015.11.025

Table 2. Liability calculations for top emitters in U.S. 2012 [75] using US\$80/ton GHG emissions.

\begin{tabular}{|l|c|c|c|c|}
\hline $\begin{array}{c}\text { Top 10 GHG Emission } \\
\text { Companies in U.S- } \\
2012\end{array}$ & $\begin{array}{c}\text { Emission } \\
\text { (Metric tons) }\end{array}$ & $\begin{array}{c}\text { Liability by } \\
\text { Polluters Pay } \\
\text { Theory (1) and } \\
\text { Producer (3) } \\
\text { (US\$ million) }\end{array}$ & $\begin{array}{c}\text { Liability by } \\
\text { Shared } \\
\text { Responsibility } \\
\text { Approach (2) } \\
\text { (US\$ million) }\end{array}$ & $\begin{array}{c}\text { Liability by } \\
\text { Consumer } \\
\text { Responsibility (4) } \\
\text { Ecological } \\
\text { Footprint } \\
\text { methodology (7) } \\
\text { (US\$ million) }\end{array}$ \\
\hline Scherer & $21,809,922$ & 1,744 & 872 & 0 \\
\hline James H Miller Jr & $18,552,161$ & 1,484 & 742 & 0 \\
\hline Rockport & $17,890,085$ & 1,431 & 715 & 0 \\
\hline Gibson & $16,900,459$ & 1,352 & 676 & 0 \\
\hline Gen J M Gavin & $16,634,356$ & 1,330 & 665 & 0 \\
\hline Bruce Mansfield & $16,271,444$ & 1,301 & 650 & 0 \\
\hline Martin Lake & $15,548,912$ & 1,243 & 621 & 0 \\
\hline Navajo Generating & $15,474,761$ & 1,237 & 618 & 0 \\
\hline Station & & & & 0 \\
\hline Monroe & $15,212,909$ & 1,217 & 608 & 0 \\
\hline Paradise & $14,932,742$ & 1,194 & 597 & \\
\hline
\end{tabular}

\subsection{Case Study: The Effects of GHG Emission Litigation on a Single Company}

To probe that potential, a case study is presented where the potential liability is calculated using equation 1 . The natural disasters and the probability of human contribution to each of them, and the estimated cost associated with each disaster were determined [74]. The probability can be considered to be $95 \%$ or higher according to the last report of IPCC in 2013 [49] and thus the majority of climate related disasters enhanced by climate change can be attributed to in part humans. The value of $Z$ will be under considerable debate for a given case, here the total IPCC probability value of anthropogenic climate change will be used for illustration. As this cost per ton of GHG emissions is likely to increase time, a sensitivity study was run on the cost per ton of GHG emissions from US\$80 to US\$2000/ton (which is approximately the ratio of the world GNP (US\$77.6 trillion) [78] to global carbon emissions (40 billion metric tons) [79]) for the top emitter in the U.S. (Scherer Power Plant) in 2012. Then using equation 1 the costs of Scherer's emissions on a global scale are quantified for 2012 for comparison.

\subsection{Potential Litigants}

Major claims already discussed in the literature are grouped into three categories: (i) interstate claims, (ii) claims that are between private persons and states, and (iii) claims between private persons. Each is discussed using examples. Potential victims of climate change are identified, which could become potential litigants and estimates of their economic impact and ability to bring fourth a lawsuit are evaluated. The Alliance of Island Nations is used as an example. Finally, the potential for class action lawsuits in this area will be summarized and discussed.

\section{Results and Discussion}

4.1 Potential GHG Emissions Liability for top 10 US Emitters

The range of liabilities for the top U.S. emitters for the seven methods have been calculated using the equations from Table 1 and the results are shown in Table 2 for 2012. In the shared responsibility approach, $\mathrm{F}_{\mathrm{e}}$ is considered to be $50 \%$, which means the responsibility is shared equally between producer and consumer. In addition, polluter's pay theory is the same as producer 
Preprint: Negin Heidari \& Joshua M. Pearce. A Review of Greenhouse Gas Emission Liabilities as the Value of Renewable Energy for Mitigating Lawsuits for Climate Change Related Damages. Renewable and Sustainable Energy Reviews 55C (2016) pp. 899-908. DOI: 10.1016/j.rser.2015.11.025

responsibility approach, and in geographical approach the producer liability is calculated in the same way; therefore, the column of liability by polluter's pay theory shows the liability by producer responsibility approach and geographical approach as well. In the published ecological footprint methodology, as all the liability is assigned to the consumers, the liability of these major polluters will be zero. The same situation exists for consumer responsibility approach. It should be noted however, a ecological footprint calculation could be used to quantify liability for emitters. In order to calculate producer liability using carbon emission added approach, emissions of intermediate systems and consumers are required; therefore, as the data was not available the producer's liability has not been calculated using this method. It can be observed in Table 2 that the maximum liability is found using polluter's pay and producer responsibility approach for top emitters, and using shared responsibility approach, the liability will be significantly reduced. Moreover, the liability of emitters will be minimum (zero) using consumer responsibility approach and the ecological footprint methodology, which also puts the economic burden of emissions litigation on consumers. The overall values of the liability are relatively small compared to the revenue of the companies shown in Table 2. However, these values are only representative of current \$/ton values for GHG emissions and thus represent the extreme minimum of potential liability for the companies if climate change related lawsuits become widespread. To gain some insight into what such potential liabilities may look like in the future a case study is presented for the top U.S. emitter below.

\subsection{Case Study: Scherer}

The inputs of the costs associated with natural disasters in the U.S. in 2012 are shown in Table 3 [74].

Table 3. Estimated Cost of Natural Disasters of 2012 in U.S. [74]

\begin{tabular}{|l|c|}
\hline Natural Disasters in $\mathbf{2 0 1 2}$ & $\begin{array}{c}\text { Estimated Cost } \\
\text { (US\$ Billion) }\end{array}$ \\
\hline U.S. Drought/Heatwave & 30 \\
\hline Western Wildfires & 66 \\
\hline Sandy & 3 \\
\hline Hurricane Isaac & 3 \\
\hline Plains/East/Northeast Severe Weather & 3 \\
\hline Rockies/Southwest Severe Weather & 2 \\
\hline Southern Plains/Midwest/Northeast Severe Weather & 3 \\
\hline Midwest/Ohio Valley Severe Weather & 1 \\
\hline Midwest Tornados & 1 \\
\hline Texas Tornados & 3 \\
\hline Southeast/Ohio Valley Tornados Cost in 2012 & 116 \\
\hline
\end{tabular}

Thus, T is US\$116 billion. The U.S. emissions for 2012 are 6,526 million metric tons [80] and the total emissions for Scherer are $21,809,922$ metric tons (or $0.33 \%$ ). Thus by equation 1, Scherer has a potential liability of approximately US\$368 million if only the costs of large-scale climate-instigated disasters are considered. This is shown as solid horizontal line on Figure 2, which is the sensitivity of total liability in 2012 for Scherer over a range of US\$10/ton to US\$2000/ton if other damages are considered using the polluters pay theory. The sensitivity is reduced to US\$200/ton and shown in Figure 3 for clarity. As can be seen in Figure 3, when the price of carbon emissions is US\$15/ton the liability is the same using polluter's pay theory and equation 1 (for only the U.S. related disasters) for Scherer in 2012. Scherer Power Plant is owned by Georgia Power, which is a subsidiary of the Southern Company (SO), which is one of the largest producers of electricity in the United States and 149th on the Fortune 500 listing of the largest U. S. corporations [81]. The total operating revenues of Scherer in 2012 was US\$7,998 million [82]. Thus, the potential liability for only climate change aggravated disasters for Scherer is US\$368 
Preprint: Negin Heidari \& Joshua M. Pearce. A Review of Greenhouse Gas Emission Liabilities as the Value of Renewable Energy for Mitigating Lawsuits for Climate Change Related Damages. Renewable and Sustainable Energy Reviews 55C (2016) pp. 899-908. DOI: 10.1016/j.rser.2015.11.025

million, which is about 4.6\% of Georgia Power's total revenue in 2012. Georgia Power is only a small part of the Southern Company whose total net income available to common shareholders was $\$ 2.09$ billion in 2014. The net income available to common shareholders are the profits remaining after the company pays all of its suppliers, employees, service providers, creditors, and preferred shareholders. Thus common shareholders of SO would see a reduction in their profits of $18 \%$ from emissions liability related to only natural disasters in the U.S. from a single coal-fired power plant [83]. These values are also small if the liability for climate related costs from other parts of the world drive up the \$/ton penalty for carbon as seen in Figure 2. If power companies began to be held liable for emissions, there would be a clear economic incentive to reduce GHG emissions by transferring electric generating resources to renewable sources of energy.

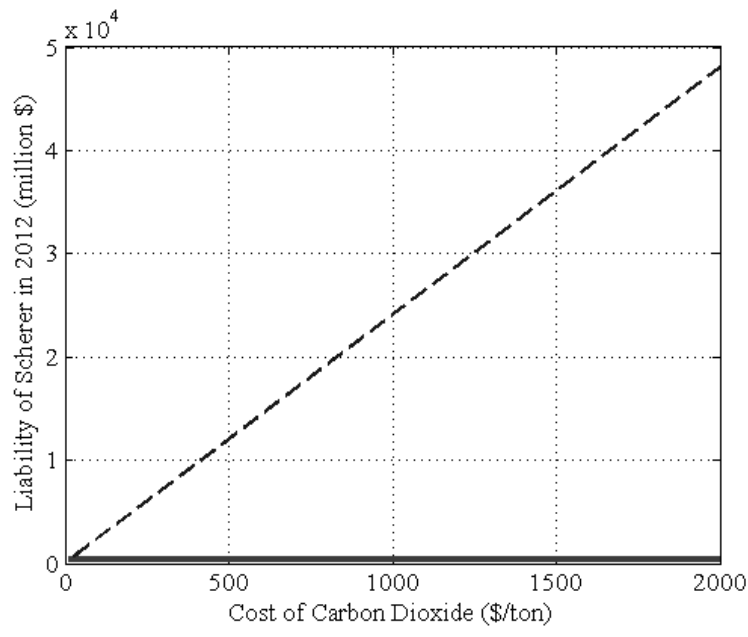

Figure 2. Sensitivity of Total Liability in 2012 for Scherer from US\$10/ton to US\$2000/ton.

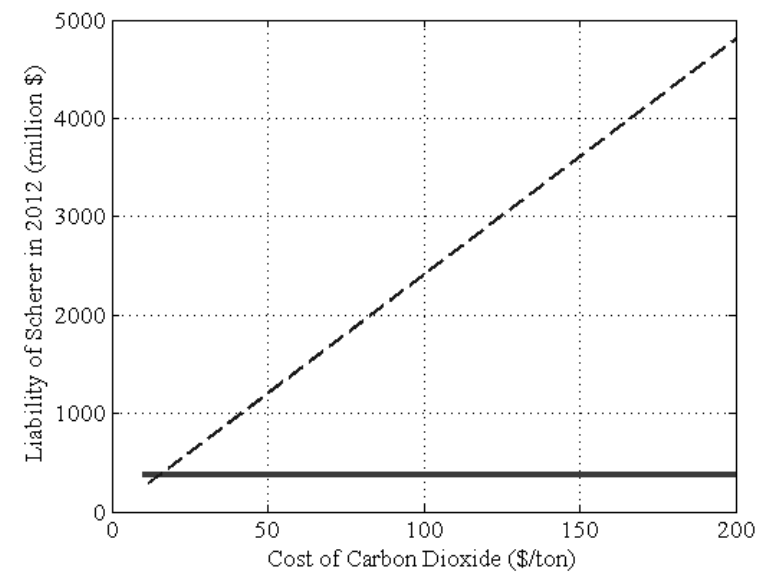

Figure 3. Sensitivity of Total Liability in 2012 for Scherer from US\$10/ton to US\$200/ton.

\subsection{Potential Types of GHG Emission Lawsuits}

Major claims already discussed in the literature can be grouped into three categories: (i) interstate claims, (ii) claims that are between private persons and states, and (iii) claims between private persons and industry [84]. In addition, there is the potential for several other forms of lawsuits including groups of states making claims against a company or companies, a company (or companies) making claims against a state, and various forms of class action lawsuits. 
Preprint: Negin Heidari \& Joshua M. Pearce. A Review of Greenhouse Gas Emission Liabilities as the Value of Renewable Energy for Mitigating Lawsuits for Climate Change Related Damages. Renewable and Sustainable Energy Reviews 55C (2016) pp. 899-908. DOI: 10.1016/j.rser.2015.11.025

\subsubsection{One Nation Suing Another}

In this case, one state brings a lawsuit in an international court to sue another state for contributing to climate change that harmed them in a quantifiable way. Historically, this type of case was unlikely to happen because states usually do not present this type of claim related to states' climate change rules in courts [84]. States suing one another is possible, but some authors have argued that putting political pressure on states to revive the process of the international debate on climate change mitigation could be a more desired outcome than forcing states to pay damages [85]. For one group of nations, lawsuits have a potentially wide appeal because of the vast scope of potential damages. For example, the destruction from the tsunami that occurred in 2009 (it claimed hundreds of thousands of lives in Island Nations and caused billions of dollars of damages) may have been amplified by climate change [86]. The risks go further than isolated disasters as the long term effect of climate change for some island nations is national annihilation. Island Nations have claimed that human activities in industrialized nations are making their islands uninhabitable because of flooding and they have been threatening to sue both the United States and Australia [86]. There are other nations that are potential targets. China, for example, is now also recognized as one of the major polluters in the world [87] and now because of economic growth possesses funds worth targeting for climate victims. In 2013, the GDP in China was worth US\$9,240 billion, which represents $14.9 \%$ of the world's economy[88]. Table 4 shows the largest emitters globally and thus potential national climate change-related defendants [89].

Table 4. Share of Global $\mathrm{CO}_{2}$ Emissions of Largest Emitter Nations in 2013 [89].

\begin{tabular}{|c|c|}
\hline Globally Largest Emitters in 2013 & Share of Global $\mathbf{C O}_{\mathbf{2}}$ Emission \\
\hline China & $22.95 \%$ \\
\hline United States & $15.5 \%$ \\
\hline India & $5.14 \%$ \\
\hline Russian Federation & $4.9 \%$ \\
\hline Brazil & $4.12 \%$ \\
\hline
\end{tabular}

To estimate the potential liability caused by the national annihilation of the Islam Nation, a 100 years of GNI growing at 3.76\%, which is the average growth rate in ten years obtained from [90] for all of the Alliance of Small Island States [91] has been calculated. This provides a rough estimate of value of economic risk from climate change for these nations. The results are shown in Table 5. So for example, Barbados has a single year potential loss of about US\$4 billion, but would need to be compensated with at least US\$4.4 trillion if the liability for annihilation based on 100 years of aggregated GNI at 3.76\% growth was used. Not all of the AOSIS nations have small economies, however. Singapore alone would account for potential liabilities of nearly US\$314 trillion if the same estimates were used.

Table 5. AOSIS nations and their current GNI and 100 year aggregate GNI with 3.76\% growth.

\begin{tabular}{|l|l|l|} 
AOSIS Members [93] & $\begin{array}{l}\text { Current GNI in } \\
\text { US\$ Billion [92] }\end{array}$ & $\begin{array}{l}\text { Aggregate of 100 years of GNI growing at } \\
\text { Antigua and Barbuda }\end{array}$ \\
\hline Bahamas & 1.177 & 1,270 \\
Barbados & 7.599 & 8,240 \\
Belize & 4.093 & 4,418 \\
Cape Verde & 1.551 & 1,674 \\
Comoros & 1.832 & 1,977 \\
Cook Islands & 0.656 & 708 \\
Cuba & N/A & N/A \\
\hline
\end{tabular}


Preprint: Negin Heidari \& Joshua M. Pearce. A Review of Greenhouse Gas Emission Liabilities as the Value of Renewable Energy for Mitigating Lawsuits for Climate Change Related Damages. Renewable and Sustainable Energy Reviews 55C (2016) pp. 899-908. DOI: 10.1016/j.rser.2015.11.025

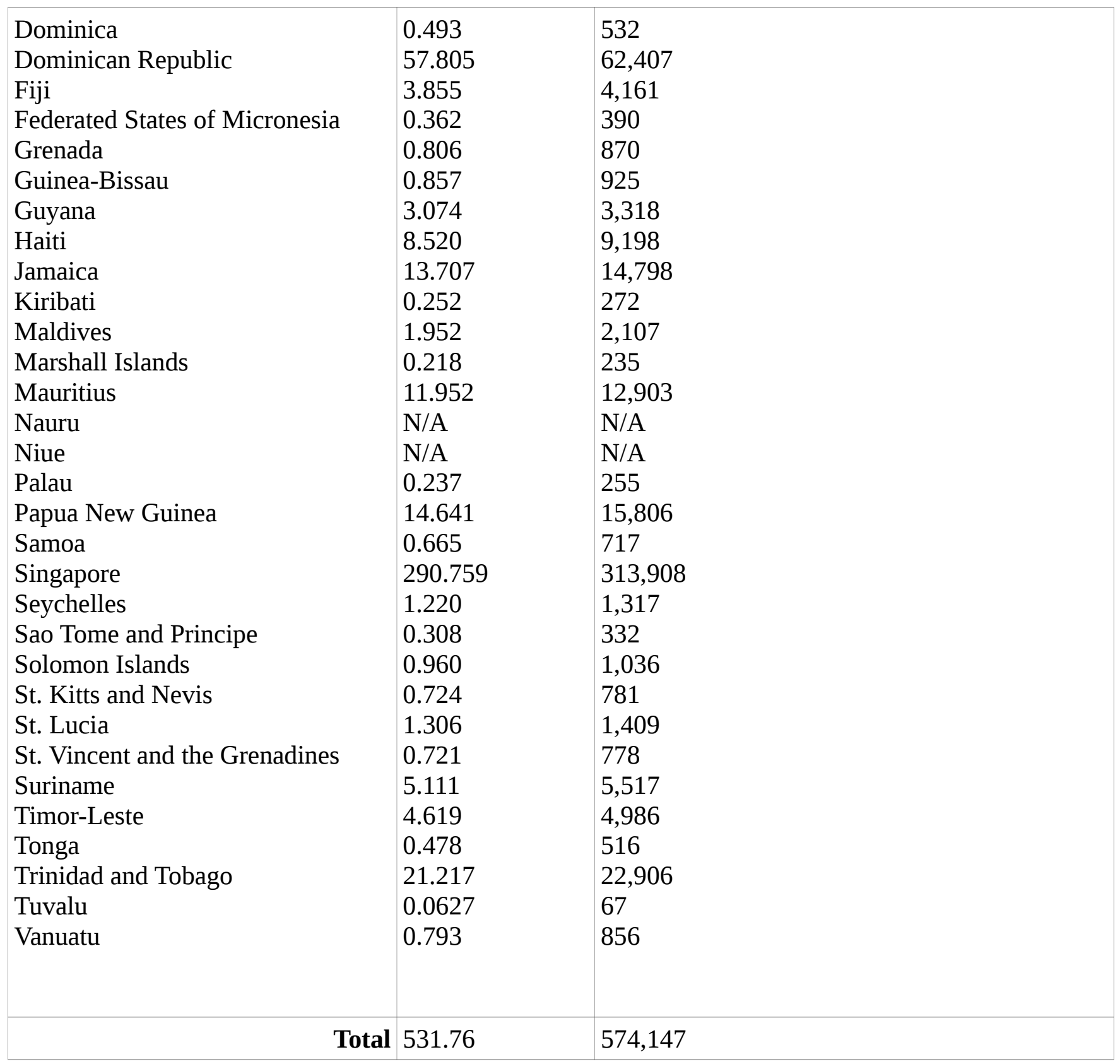

\subsubsection{David vs Goliath I: Private Persons Suing a State}

In the second type of case, which has already occurred, private persons suffering from climate change losses can take legal actions against states, whether their own state or a foreign state, that have contributed to climate change through GHG emissions. Most individuals do not have the capital reserves to mount a protracted legal campaign against a state. However, in this same class, other sub-state entities could take legal actions against states. For example, the state of Alaska could litigate against United States as a whole [84]. Such cases can be tried in an international court of law if violations of human rights are involved in the case. 
Preprint: Negin Heidari \& Joshua M. Pearce. A Review of Greenhouse Gas Emission Liabilities as the Value of Renewable Energy for Mitigating Lawsuits for Climate Change Related Damages. Renewable and Sustainable Energy Reviews 55C (2016) pp. 899-908. DOI: 10.1016/j.rser.2015.11.025

\subsubsection{David vs Goliath II: Private Persons of a State Suing Industry}

In the third type of case, private persons harmed by climate change can litigate against GHG emitters, also a state can take legal actions against individual $\mathrm{CO}_{2}$ emitters. For instance, Ned Comer took legal actions against Murphy Oil U.S.A Incorporation due to their GHG emission, which contributed to hurricane Katrina and subsequently caused damages to the environment, property, and public health [94]. In this case, unlike the previous scenario, claims need to be brought to the domestic courts [84]. Again most individuals do not have the capital reserves to mount a protracted legal campaign against a large corporation. In scenarios that victims sue in the foreign state it would need to be determined if the plaintiff has access to a court in a place in which the damages occurred. Provisions exist in the U.S. that allow the foreign plaintiffs to litigate in the United States courts. If the amount is higher than US\$75,000 then U.S. courts may have the power over cases between U.S citizens and foreigners, or foreign states [84]. Another issue is that a foreign victim of climate change can find a liability administration that is relevant to climate change. A plaintiff can also bring a claim in his or her state against a foreign litigant, which is more preferable because the costs will be much lower, and usually the plaintiffs expect the court in his own state to be more sympathetic towards their cases [84].

\subsubsection{Group Lawsuits from States or Companies}

The following types of lawsuits have not yet been detailed in the literature, but are potential sources of liability for GHG emitters. to The first three variations involve some form of class action and are based off of the three main types detailed above.

First, many states could form an alliance to sue a single nation or a group of emitter nations. For example, AOSIS is an existing coalition of small island and low-lying coastal countries that share similar development challenges and concerns about the environment, especially their vulnerability to the adverse effects of global climate change [91]. This coalition currently has 44 States and observers, of which 37 are members of the United Nations, representing more than a quarter of developing countries, and $20 \%$ of the UN's total membership. AOSIS could pool their resources and begin to sue either the greatest historical emitter (U.S.) or current emitter (China) for damages that amount to the AOSIS entire GNP summed over some significant expanse of time (as shown in Table 5) as climate change is an existential risk to these nations. The GNI of the United States in 2013 was 16.992 trillion USD, and GNI of China was 9.196 trillion USD in 2013 [95]. It can be seen from Table 5 that total GNI of AOSIS members in 2013 is equal to $\$ 531.76$ billion, and a total of 100 years of GNI growing at 3.76\% is equal to $\$ 574$ trillion. The GNI of 3 members of AOSIS were not available and marked as such in Table 5 [92]. Thus, although these values are substantial, the totals can be viewed as an underestimate of potential liability. Thus, it can be seen that GNI of AOSIS members in a single year is inconsequential to the aggregate of China and the U.S. economies. However, if AOSIS was compensated for 100 years of future losses the impact would be 574 trillion USD if the island nations were lost in 2014 and thus the loss is much greater than the GNI of either China or the U.S. for a single year.

Second, a company or group of companies can litigate against another company. For example, a company such as Coca Cola or Nike that has been adversely affected severely by flooding and droughts [96] can take legal class actions against an oil company, which is known to be a major emitter. Coca Cola company lost its license in India due to water shortage in 2004, and thus the balance sheet of the Coke Company has been damaged as the water that is required to produce its soda has been lost to droughts; therefore, the idea of climate change as a disruptive force on the economic bottom line is now accepted by the company [96]. Similarly, Nike owns 700 factories in about 49 countries, and extreme weather has been disrupting its supply chains, which catalyzed Nike to speak out against climate change. Four Nike factories were temporarily shut down in Thailand due to flooding in 2008. Nike uses cotton in the clothes it makes, and it is concerned about the droughts in producing cotton regions [96].

Both Nike and Coke companies are already persuading governments to enact policies that are environmentally friendly to protect their profits [96] and have the size, capital reserves and legal sophistication to weather a protracted legal battle. If profits for companies began to be severely impacted by climate change individual and collective legal action could occur. In addition, companies could help engage customers and shareholders in class action suits to protect their profits.

\subsubsection{Company Lawsuit Against a State}

There is already some evidence companies may even sue states for enacting legislation which causes profit losses. For example, Quebec recently halted fracking practices to extract oil, but a U.S. company, Lone Pine Resources Inc., sued in response for \$250 million to compensate it for investments already made in the sector and for lost profits [97]. Also, Philip 
Preprint: Negin Heidari \& Joshua M. Pearce. A Review of Greenhouse Gas Emission Liabilities as the Value of Renewable Energy for Mitigating Lawsuits for Climate Change Related Damages. Renewable and Sustainable Energy Reviews 55C (2016) pp. 899-908. DOI: 10.1016/j.rser.2015.11.025

Morris sued Australia for billions of dollars in damages because the government passed a law requiring plain packaging in order to reduce tobacco use [98]. Likewise Swedish energy giant Vattenfall is suing Germany for €3.7 billion over new laws ordering the phase-out of all nuclear power plants and a shift to clean energy [99]. It is thus possible companies could begin suing and leading class action lawsuits not only against each other for climate related losses to future profit, but also nations that did not enact GHG emission reduction legislation.

\subsubsection{Sub-national Entity Lawsuits Against a Company}

Third, a state can sue a company for climate change damages. For example, the state of California in the U.S., which is facing droughts and flooding disasters that causes substantial economical damages [100,101] can litigate against a coal company that is a major polluter or any company that contributes to these climate change-related costs. Another example is Kivalina v. ExxonMobil Corporation, et al. This case was filed on a United States district court on February 2008, and monetary compensation has been claimed from the energy industry because of the destruction of Kivalina, Alaska which occurred due to a flooding. The damage has been estimated to be between $\$ 95$ and \$400 million. The United States district court dismissed the case [102]. A case was also filed against General Motors by the California State seeking for compensation [67], which was also dismissed [103]. The case was brought to the federal district court and two causes of action were asserted for public nuisance, one was under California law and the other was under federal common law [67].

\subsubsection{Crowd Sourced Lawsuits}

The concept of crowd sourcing is gaining traction from such diverse applications as scientific research (e.g NASA's photograph organizing project or the National Audubon Society's Christmas Day Bird Census) to business start up crowdfunding (e.g. Kick Starter and Indiegogo). Crowd sourcing can be applied to climate litigation through funding and instituting class action lawsuits. A class action lawsuit could be filed against a state for harm done to a collection of individuals. For example, wealthy home owners along the U.S. eastern coast could form an alliance for a class action lawsuit as their luxury and vacation homes are becoming increasingly difficult to insure due to the high probability of damage from climate change augmented natural disasters [104,105]. Potential law changes associated with flood insurance could significantly increases rates or make buildings uninsurable. Flood insurance is currently subsidized by the Robert T. Stafford Disaster Relief and Emergency Assistance Act (Stafford Act), the federal law governing the response to emergencies like hurricanes, wildfires and tornadoes, which comes into force when the president declares a federal disaster that exceeds the response capacity of state and local governments [106]. There is significant political pressure already being applied to alter or eliminate the Stafford Act [107]

Lastly, class action lawsuits could be filed against a company (or companies) by a collection of individuals. These can be the same individuals above who find it difficult or impossible to insure their homes and businesses in areas with high probabilities of climate-related disaster. There are ample examples of this type of lawsuit in regards to other pollutants. These lawsuits can also be filed by NPOs or environmental groups. For example Friends of the Earth, Inc. et al. v. Laidlaw Environmental Services, Inc. was heard at the United States Supreme Court. The residents of South Carolina's North Tyger River claimed that they could not use the river for amusement purposes due to the pollution, and court held that they had a standing to litigate against the polluter [108].

As of this writing, the case American Electric Power Company v. Connecticut provides GHG emitters with temporary protection from climate-change related mitigation. The case was decided by the U.S. Supreme Court, which held that corporations can not be litigated for emissions of greenhouse gases because the management of carbon dioxide and other greenhouse gases are delegated to Environmental Protection Agency (EPA). This has been the first global warming case that was based on a public nuisance claim (when villages are destroyed because of coastal erosion and melting sea ice and when erosion and rising sea level cause the public land and beaches to get lost, then these effects show the interference with public rights [66]). Eight States separately sued the same corporations and the court dismissed the plaintiff's claim as non-justiciable [109]. As the scientific evidence of GHG emissions resulting in climate destabilization continue to mount and the damages from climate change increase it is likely that such cases will become more common. The EPA jurisdiction over GHG emissions is under constant flux. For example, Massachusetts v. Environmental Protection Agency, which was decided in the U.S. Supreme court, was a suit was brought to the court by several states against the EPA in order to force the EPA to control greenhouse gases as pollutants [110]. 
Preprint: Negin Heidari \& Joshua M. Pearce. A Review of Greenhouse Gas Emission Liabilities as the Value of Renewable Energy for Mitigating Lawsuits for Climate Change Related Damages. Renewable and Sustainable Energy Reviews 55C (2016) pp. 899-908. DOI: 10.1016/j.rser.2015.11.025

\subsection{Limitations}

It should be noted here that one of the primary limitations of this study is that it is based on the U.S. legal system, rather than on the broader International Law system that is more widely accepted by most countries. Future work is needed to expand the scope of this work to the International Law system. Utilizing the U.S. legal system here introduces a bias and thus leads to risk of civil lawsuits that can only be covered in U.S. courts and not in international courts in situations when U.S. courts would have no jurisdiction. Thus, the approach described here, although relevant, should only be utilized as a first approach. This first approach should act as only a first approximation for GHG emission-related liability for an individual emitter. The existence of other legal systems, particularly those based on Code Law rather than Common Law, has to be covered in future work to obtain the full scope of the complexity of such potential lawsuits and emission-related liability. Thus, all of the results should be treated as conservative estimates on the overall liability for a company (and thus as underestimates of the value of deploying RETs to offset GHG emissions).

\subsection{Summary of Additional Value for RETs}

In summary, as it becomes clear that climate change caused by GHG emissions can cause serious economic harm $[26,36,39,43,111-113]$ and before global society moves to a net energy based economy or one based on life-cycle carbon emissions [114,115], companies and nations responsible for GHG emissions may have serious liability issues. All of the potential liabilities quantified in this study represent the potential values of deploying RETs. It should be pointed out that this value is in addition to the value of the sustainable energy the RETs produce. Current emitters can reduce their liability by investing in renewable and sustainable energy technologies to reduce their GHG emissions. RETs such as solar PV have a well established record of providing a sustainable source of electricity while mitigating greenhouse gas emissions [116]. Other RETs such as wind energy, geothermal, hydropower, and bioenergy can be utilized to mitigate the liability of these potential emitters by providing power without emitting greenhouse gases [117]. Therefore, all of these RETs reduce the liability associated with emissions of GHG's for entities that utilize them. As shown by the results here, for some companies this could be worth billions of dollars a year - far more than the cost of the investment in the RET to cover the equivalent energy production. In addition, for many energy consumers, RET-generated electricity already offer competitive financial returns without taking this liability into account. For example, investors have noted that in the PV sector in the U.S. the securtization of residential solar PV assets can be highly profitable [118]. If climate change related lawsuits become the norm this profitability would increase substantially as those with liability bid for ownership of RET assets to reduce their risk. It should be pointed out here that the liability for companies could also be based on embodied emissions [119], which means that former emitters may benefit from investment in RETs to mitigate their risk even if the nature of their enterprise no longer relies in a large extent to the combustion of fossil fuels for energy. However, there is still considerable debate on carbon accounting [120] as well as significant uncertainty to the degree emitters will be held responsible for mounting economic losses from GHG emission caused climate destabilization. The results of this review are clear that conservative financial management indicate that it is not only current emitters that should look to RETs as sources of liability mitigation, as former or historic emitters (e.g. nations) could also utilize the carbon offset by current deployment of sustainable and renewable energy technologies to help defend themselves in the courts of the future.

\section{Conclusions}

In this study the methods to quantify liability for climate change have been reviewed. The potential litigants that are well positioned to bring emission related lawsuits include those that are most threatened that have political organization such as the Island Nations making up OASIS. However, other entities such as individual nations, states, or companies that have financial losses due to climate change could seek compensation in court from emitters. Finally individuals alone or as part of class action lawsuits organized by non-profits or law firms can file lawsuits against GHG emitters. The results showed liability is maximized when it is assigned either by the polluters pay theory or if producers are held solely responsible for emissions. The case study presented here showed that the liability associated only with U.S. disasters associated with GHG emissions from a single fossil fuel plant can have a significant negative impact on the profits of even major electric providers. Depending on the liability cost of carbon coal-fired power plants are exposed to lawsuits ranging from hundreds of millions to billions of dollars within the U.S. These potential liabilities increase into the trillions of dollars when economic losses from 
Preprint: Negin Heidari \& Joshua M. Pearce. A Review of Greenhouse Gas Emission Liabilities as the Value of Renewable Energy for Mitigating Lawsuits for Climate Change Related Damages. Renewable and Sustainable Energy Reviews 55C (2016) pp. 899-908. DOI: 10.1016/j.rser.2015.11.025

climate change are taken into account globally. The results show that potential liability for climate change for the Alliance of Small Island States is over \$570 trillion. It is concluded that as emitters begin to be held liable for damages resulting from GHG emissions resulting in climate change, a high value for liability mitigation would provide additional powerful incentives for deployment of renewable energy technologies. Large GHG emitters, such as fossil fuel-based power plants, can begin to mitigate the risks associated with present and future liabilities by proactively investing in renewable energy technologies. As more climate-change cases are brought to court this economic incentive to convert to renewable energy is expected to accelerate.

\section{References}

[1]. Demirbas A. Potential applications of renewable energy sources, biomass combustion problems in boiler power systems and combustion related environmental issues. Progress in Energy and Combustion Science, vol. 31, no. 2. 2005;171192.

[2]. Anita B, Babypriya B. Modelling, simulation and analysis of doubly fed induction generator for wind turbines. Journal of Electrical Engineering, vol. 60, no. 2. 2009;79-85.

[3]. Kishore A, Prasad R, Karan B. Matlab simulink based DQ modeling and dynamic characteristics of three phase self excited induction generator. in Proceedings of the Progress in Electromagnetics Research Symposium, Cambridge (USA), 2006;312-316.

[4]. Haines A, Kovats R, Campbell-Lendrum D, Corvalan C. Climate change and human health: Impacts, vulnerability and public health. Public Health, vol. 120, no. 7. 2006;585-596.

[5]. Rabl A, Spadaro J. Public health impact of air pollution and implications for the energy system. Annual review of Energy and the Environment, vol. 25, no. 1. 2000;601-627.

[6]. Martinot E, Chaurey A, Lew D, Moreira J, Wamukonya N. RENEWABLE ENERGY MARKETS IN DEVELOPING COUNTRIES. Annual Review of Energy and the Environment, vol. 27, no. 1. 2002;309-348.

[7]. Haines A, McMichael AJ, Smith KR, Roberts I, Woodcock J, Markandya A, Armstrong BG, Campbell-Lendrum D, Dangour AD, Davies M. Public health benefits of strategies to reduce greenhouse-gas emissions: overview and implications for policy makers. The Lancet, vol. 374, no. 9707. 2010;2104-2114.

[8]. Wei M, Patadia S, Kammen DM. Putting renewables and energy efficiency to work: How many jobs can the clean energy industry generate in the US?. Energy Policy, vol. 38, no. 2. 2010;919-931.

[9] Geller H, Schaeffer R, Szklo A, Tolmasquim M. Policies for advancing energy efficiency and renewable energy use in Brazil. Energy Policy, vol. 32, no. 12. 2004;1437-1450.

[10] Branker K, Pathak MJM, Pearce JM. A review of solar photovoltaic levelized cost of electricity. Renewable and Sustainable Energy Reviews, vol. 15, no. 9. 2011;4470-4482.

[11]. Clean Renewable Energy. Available at<http://www.renewable-energy-forum.ca/clean-renewable-energy.html $>$ (Accessed on 18 October 2014)

[12]. Australian Energy Resource Assessment. Wind Energy. Available at $<\underline{\text { http://arena.gov.au/files/2013/08/Chapter-9-Wind- }}$ Energy.pdf> (Accessed on 18 October 2014)

[13] SEIA. Photovoltaic (Solar Electric). Available at $<$ http://www.seia.org/policy/solar-technology/photovoltaic-solarelectric $>$ (Accessed on 18 October 2014)

[14] AWEA. Power here Builds more Power there. Available at $<$ http://www.awea.org/Advocacy/content.aspx? ItemNumber $=797>$ (Accessed on 18 October 2014)

[15]. El-Fadel M, Chedid R, Zeinati M, Hmaidan.Mitigating W. energy-related GHG emissions through renewable energy. Renewable Energy, vol. 28, no. 8. 2003;1257-1276.

[16]. Granovskii M, Dincer I, Rosen M. Greenhouse gas emissions reduction by use of wind and solar energies for hydrogen and electricity production: Economic factors. International Journal of Hydrogen Energy, vol. 32, no. 8. 2007 ;927-931.

[17]. Sims RH. Renewable energy: a response to climate change. Solar Energy, vol. 76, no. 1-3. 2004 ; 9-17.

[18]. Tsoutsos T, Papadopoulou E, Katsiri A, Papadopoulos AM. Supporting schemes for renewable energy sources and their impact on reducing the emissions of greenhouse gases in Greece. Renewable and Sustainable Energy Reviews, vol. 12, no. 7. 2008;1767-1788. 
Preprint: Negin Heidari \& Joshua M. Pearce. A Review of Greenhouse Gas Emission Liabilities as the Value of Renewable Energy for Mitigating Lawsuits for Climate Change Related Damages. Renewable and Sustainable Energy Reviews 55C (2016) pp. 899-908. DOI: 10.1016/j.rser.2015.11.025

[19]. Longo A, Markandya A, Petrucci M. The internalization of externalities in the production of electricity: Willingness to pay for the attributes of a policy for renewable energy. Ecological Economics, vol. 67, no. 1. 2008;140-152.

[20]. Tilman D, Balzer C, Hill J, Befort BL. Global food demand and the sustainable intensification of agriculture. PNAS, vol. 108, no. 50. 2011;20260-20264.

[21]. Pizer WA. Combining price and quantity controls to mitigate global climate change. Journal of public economics, vol. 85, no. 3. 2002;409-434.

[22]. Garnett T. Livestock-related greenhouse gas emissions: impacts and options for policy makers. Environmental Science \& Policy, vol. 12, no. 4. 2009;491-503.

[23]. Peters GP, Hertwich EG. $\mathrm{CO}_{2}$ Embodied in International Trade with Implications for Global Climate Policy. Environmental Science \& Technology, vol. 42, no. 5. 2008;1401-1407.

[24]. Riebesell U, Zondervan I, Rost B, Tortell PD, Zeebe RE, Morel FM. Reduced calcification of marine plankton in response to increased atmospheric CO2. Nature, vol. 407, no. 6802. 2000;364-367.

[25]. Moss RH, Edmonds JA, Hibbard KA, Manning MR, Rose SK,. Van Vuuren DP, Carter TR, Emori S, Kainuma M, Kram T, Meehl GA, Mitchell JF, Nakicenovic N, Riahi K, Smith SJ, Stouffer RJ, Thomson AM, Weyant JP, Wilbanks TJ. The next generation of scenarios for climate change research and assessment. Nature, vol. 463, no. 7282. 2010;747756.

[26]. Stern Review. The Economics of Climate Change. Available at < $\underline{\text { http://webarchive.nationalarchives.gov.uk/ }}$ +/http:/www.hm treasury.gov.uk/media/4/3/executive summary.pdf > (Accessed on 18 October 2014)

[27]. Fouillet A, Rey G, Laurent F, Pavillon G, Bellec S, Guihenneuc-Jouyaux C, Clavel J, Jougla E, Hémon D. Excess mor tality related to the August 2003 heat wave in France. International Archives of Occupational and Environmental Health, vol. 80, no. 1. 2006;16-24.

[28]. Dhainaut JF, Claessens YE, Ginsburg C, Riou B. Unprecedented heat-related deaths during the 2003 heat wave in Paris: consequences on emergency departments. Critical Care, vol. 8, no. 1. 2003; 1.

[29]. Poumadère M, Mays C, Le Mer S, Blong R. The 2003 Heat Wave in France: Dangerous Climate Change Here and Now: The 2003 Heat Wave in France. Risk Analysis, vol. 25, no. 6. 2005;1483-1494.

[30]. D’Amato G, Cecchi L. Effects of climate change on environmental factors in respiratory allergic diseases. Clinical \& Experimental Allergy, vol. 38, no. 8. 2008;1264-1274.

[31]. Joint ICES/CIESM Workshop to Compare Zooplankton Ecology and Methodologies between the Mediterranean and the North Atlantic (WKZEM), Ed., Proceedings of the Joint ICES/CIESM Workshop to Compare Zooplankton Ecology and Methodologies between the Mediterranean and the North Atlantic (WKZEM). Copenhagen, Denmark: ICES, International Council for the Exploration of the Sea, 2010.

[32]. Parry ML, Rosenzweig C, Iglesias A, Livermore M, Fischer, G. Effects of climate change on global food production under SRES emissions and socio-economic scenarios. Global Environmental Change. 2004;14(1), 53-67.

[33]. Schmidhuber J, Tubiello FN. Global food security under climate change. Proceedings of the National Academy of Sciences. 2007;104(50), 19703-19708.

[34]. Parry M, Rosenzweig C, Livermore M. Climate change, global food supply and risk of hunger. Philosophical Transactions of the Royal Society B: Biological Sciences. 2005;360(1463), 2125-2138.

[35]. Klinenberg E. Are You Ready for the Next Disaster?. New York Times Magazine, 2008.

[36]. Vine E. Adaptation of California’s electricity sector to climate change. Climatic Change, vol. 111, no. 1. 2012;75-99.

[37]. Frihy OE. The Nile delta-Alexandria coast: vulnerability to sea-level rise, consequences and adaptation. Mitigation and Adaptation Strategies for Global Change, vol. 8, no. 2. 2003;115-138.

[38]. Moorhead KK, Brinson MM. Response of Wetlands to Rising Sea Level in the Lower Coastal Plain of North Carolina. Ecological Applications, vol. 5, no. 1. 1995;261.

[39]. Nicholls RJ, Hoozemans FM, Marchand M. Increasing flood risk and wetland losses due to global sea-level rise: regional and global analyses. Global Environmental Change, vol. 9. 1999;S69-S87.

[40]. Bobba AG. Numerical modelling of salt-water intrusion due to human activities and sea-level change in the Godavari Delta, India. Hydrological Sciences Journal, vol. 47, no. sup1. 2002;S67-S80.

[41]. Desantis LG, Bhotika S, Williams K, Putz FE. Sea-level rise and drought interactions accelerate forest decline on the Gulf Coast of Florida, USA. Global Change Biology, vol. 13, no. 11. 2007;2349-2360. 
Preprint: Negin Heidari \& Joshua M. Pearce. A Review of Greenhouse Gas Emission Liabilities as the Value of Renewable Energy for Mitigating Lawsuits for Climate Change Related Damages. Renewable and Sustainable Energy Reviews 55C (2016) pp. 899-908. DOI: 10.1016/j.rser.2015.11.025

[42]. Allen CD, Macalady AK, Chenchouni H, Bachelet D, McDowell N, Vennetier M, Kitzberger T, Rigling A, Breshears DD, Hogg EH, Gonzalez P, Fensham R, Zhang Z, Castro J, Demidova N, Lim JH, Allard G, Running SW, Semerci A, Cobb N. A global overview of drought and heat-induced tree mortality reveals emerging climate change risks for forests. Forest Ecology and Management, vol. 259, no. 4. 2010;660-684.

[43]. Dale VH, Joyce LA, Mcnulty S, Neilson RP, Ayres MP, Flannigan MD, Hanson PJ, Irland LC, Lugo AE, Peterson CJ, Simberloff D, Swanson FJ, Stocks BJ, Michael Wotton B. Climate Change and Forest Disturbances. BioScience, vol. 51, no. 9. 2001;723.

[44]. Carnicer J, Coll M, Ninyerola M, Pons X, Sanchez G, Penuelas J. Widespread crown condition decline, food web disruption, and amplified tree mortality with increased climate change-type drought. Proceedings of the National Academy of Sciences, vol. 108, no. 4. 2011;1474-1478.

[45]. Dai A. The Increased Risk of Drought under Global Warming. Available at $<\underline{\text { http://www.wunderground.com/earth- }}$ day/2013/increased risk of drought under global warming $>$ (Accessed on 18 October 2014)

[46]. Flannigan M, Stocks B, Turetsky M, Wotton M. Impacts of climate change on fire activity and fire management in the circumboreal forest. Global Change Biology, vol. 15, no. 3. 2009;549-560.

[47]. Amiro BD, Stocks BJ, Alexander ME, Flannigan MD, Wotton B.M. Fire, climate change, carbon and fuel management in the Canadian boreal forest. International Journal of Wildland Fire 10. 2001;405-413.

[48]. UN News Centre. (2014) Available at < http://www.un.org/apps/news/story.asp?NewsID=47047\#.VDLw1BaaXGU $>$ (Accessed on 6 October 2014).

[49]. IPCC Fifth Assessment Report. (2013) Available at < http://www.ipcc.ch/publications and data/publications and data reports.shtml> (Accessed on 29 September 2014).

[50]. Cason TN. Buyer liability and voluntary inspections in international greenhouse gas emissions trading: a laboratory study. Environmental and Resource Economics, vol. 25, no. 1. 2003;101-127,.

[51]. Ellerman AD, Joskow PL. The European Union's emissions trading system in perspective. Pew Center on Global Climate Change Arlington, VA, 2008.

[52]. How Things Work: Carbon Trading. (2010) Available at < http://ourworld.unu.edu/en/the-pros-and-cons-of-carbontrading $>$ (Accessed on 6 October 2014).

[53]. Andersen G, Sullivan D, National Conference of State Legislatures, Reducing greenhouse gas emissions: carbon cap and trade and the carbon tax. 2009.

[54]. Schiller B. Europe’s Co2 Trading Scheme: It is Time for a Major Overhaul? (2011) Available at < http://e360.yale.edu/feature/europes co2 trading scheme is it time for a major overhaul/2396/> (Accessed on 6 October 2014)

[55]. Ares A. Carbon Price Floor. Science and Environmental Section. 2014

[56]. Richey S. The Pros and Cons of Cap and Trade. (2010) Available at < http://www.steverichey.com/writingsamples/climate-change/the-pros-and-cons-of-cap-and-trade/> (Accessed on 6 October 2014).

[57]. Lang C. The EU Emissions Trading Scheme has failed: “Time to scrap the ETS”. (2013). Available at < http://www.redd-monitor.org/2013/04/16/the-eu-emissions-trading-scheme-has-failed-time-to-scrap-the-ets/> (Accessed on 6 October 2014).

[58]. Bohm S. Why are carbon markets failing? (2013) Available at $<$ http://www.theguardian.com/sustainablebusiness/blog/why-are-carbon-markets-failing > (Accessed on 6 October 2014).

[59]. Sinclair M. The Expensive Failure of the European Union Emissions Trading Scheme. TaxPayers’ Alliance, October, 2009.

[60]. Preston BJ. The influence of climate change litigation on governments and private sectors. Available at: http://www.lec.justice.nsw.gov.au/agdbasev7wr/ assets/lec/m4203011721754/preston influence\%20of\%20climate \%20change\%20litigation.pdf (Accessed on 6 October 2014)

[61]. Farber D. Basic Compensation for the Victims of Climate Change. University of California, Berkeley Public Law Research. Paper No. 954357. 2006.

[62]. Farber D. The case for climate compensation justice for climate change victims in a complex world. Utah Law Review. 2008.

[63]. Hancock E. Red Dawn, Blue Thunder, Purple Rain: Corporate Risk of Liability for Global Climate Change and the SEC Disclosure Dilemma. Georgetown Environmental Law Review; Winter 2005; vol. 17. 2005; $233-251$. 
Preprint: Negin Heidari \& Joshua M. Pearce. A Review of Greenhouse Gas Emission Liabilities as the Value of Renewable Energy for Mitigating Lawsuits for Climate Change Related Damages. Renewable and Sustainable Energy Reviews 55C (2016) pp. 899-908. DOI: 10.1016/j.rser.2015.11.025

[64]. Healy K, Tapick J. Climate Change: It's Not Just a Policy Issue for Corporate Counsel - It's a Legal Problem. Columbia Journal of Environmental Law, Entvl. L. 89. 2004;1-23.

[65]. Grossman D. Warming up to a not-so-radical idea: Tort-based climate change litigation. Columbia Journal Of Environ mental Law. J. Envtl. L. 1. 2003.

[66]. Kilinsky J. International climate change liability: A myth or a reality. J. Transnat'l L. \& Pol'y, vol. 18. $2008 ; 377$.

[67]. Farber DA. Tort Law in the Era of Climate Change, Katrina, and 9/11: Exploring Liability for Extraordinary Risks. Val. UL Rev., vol. 43. 2008;1075.

[68]. Farber DA. Apportioning Climate Change Costs. UCLA J. Envtl. L. \& Pol’y, vol. 26. 2008;21.

[69]. Allen M. Liability for climate change, Nature, vol. 421, no. 6926. 2003;891-892.

[70]. Reimund S. Liability for Climate Change: The Benefits, the Costs, and the Transaction Costs. Responses to Global Warming: The Law, Economics, and Science of Climate Change, vol. 155, no. 6. 2007;1947-1952.

[71] Lenzen M, Murray J, Sack F, Wiedmann T. Shared producer and consumer responsibility — Theory and practice. Ecological Economics, vol. 61, no. 1. 2007;27-42.

[72]. Bastianoni S, Pulselli FM, Tiezzi E. The problem of assigning responsibility for greenhouse gas emissions. Ecological Economics, vol. 49, no. 3. 2004;253-257.

[73]. Wackernagel M, Rees WE. Our Ecological Footprint: Reducing Human Impact on the Earth. New Society, Gabriola Island, BC, Canada. 1996;176.

[74]. NOAA National Climate Data Center. Billion-Dollar Weather and Climate Disasters: Table of Events. (2013) Available at <http://www.ncdc.noaa.gov/billions/events>

[75]. EPA. Greenhouse Gas Emissions from Large Facilities. (2013) Available at < http://ghgdata.epa.gov/ghgp/main.do > (Accessed on 14 October 2014)

[76]. EAUC. Calculation of the Ecological Footprint Print of the University of Limerick’s A4 paper use. Available at $<$ http://webcache.googleusercontent.com/search?

q=cache:kDTEsfh6XokJ:www.eauc.org.uk/file uploads/7 calculation of the ef of a4 paper use by nicola hogan. $\mathrm{ppt}+\& \mathrm{~cd}=1 \& \mathrm{hl}=\mathrm{en} \& \mathrm{ct}=\mathrm{clnk} \& \mathrm{gl}=\mathrm{us}>($ Accessed on 23 November 2014)

[77]. CDP. Global corporate use of carbon pricing. (2014) Available at $<$ https://www.cdp.net/cdpresults/global-price-oncarbon-report-2014.pdf > (Accessed on 23 November 2014)

[78]. Malpass D. Economic Policies for the 21st Century at the Manhattan Institute. (2014). Available at < http://www.economics21.org/commentary/encima-global-projects-world-gdp-will-shrink-2015> (Accessed on 24 January 2015)

[79]. Oskin B. Livescience. Global Carbon Emissions Reach New Record High. (2014). Available at <http://www.livescience.com/47929-global-carbon-emissions-2014-record.html> (Accessed on 24 January 2015)

[80]. EPA. National Greenhouse Gas Emissions Data. (2015) Available at <http://www.epa.gov/climatechange/ghgemissions/usinventoryreport.html > (Accessed on 24 January 2015)

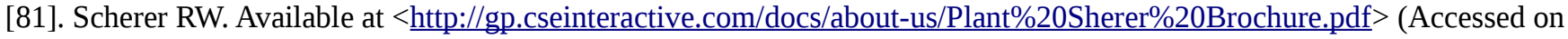
27 January 2015)

[82]. 2012 Annual Report of Georgia Power Company. (2013) Available at < $\underline{\text { http://www.georgiapower.com/docs/about- }}$ us/2012-Annual-Report.pdf> (accessed on January 27, 2015)

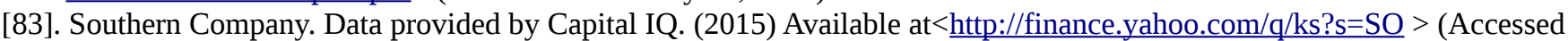
on 1 February 2015)

[84]. Faure MG, Nollkaemper A. International liability as an instrument to prevent and compensate for climate change. A Stan. Envtl. LJ, 2007;26, 123.

[85]. McDermott M. Existing International Law Supports States Suing One Another Over Climate Change Damages. (2010)

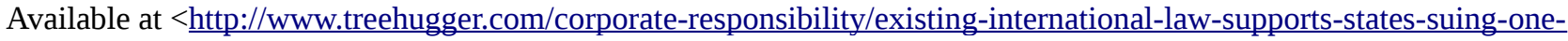
another-over-climate-change-damages.html> (Accessed on 27 October 2014). 2010

[86]. Fabio M. Island Nations may sue U.S. over climate change. Legal Zoom. (2009) Available at <https://www.legalzoom.com/articles/island-nations-may-sue-us-over-climate-change> (Accessed on 30 September 2014).

[87]. Zeng N, Ding Y, Pan J, Wang H, Gregg J. Climate change_the Chinese challenge. Science 319, 2008 ;730-731. 
Preprint: Negin Heidari \& Joshua M. Pearce. A Review of Greenhouse Gas Emission Liabilities as the Value of Renewable Energy for Mitigating Lawsuits for Climate Change Related Damages. Renewable and Sustainable Energy Reviews 55C (2016) pp. 899-908. DOI: 10.1016/j.rser.2015.11.025

[88]. Trading Economics. China GDP. (2014) Available at $<$ http://www.tradingeconomics.com/china/gdp $>$ (Accessed on 27 October 2014).

[89]. Statista. The Statistics Portal. The largest producers of CO2 emissions worldwide in 2014, based on their share of global CO2 emissions. (2013) Available at <http://www.statista.com/statistics/271748/the-largest-emitters-of-co2-in-theworld/> (Accessed on 14 October 2014)

[90]. Real Growth Rate. (2011) Available at $<\underline{\text { http://www.indexmundi.com/g/g.aspx?c }=x x \& v=66>}>$ (Accessed on 4 December 2014)

[91]. AOSIS. Alliance of Small Island States. (2014) Available at $<$ http://aosis.org/about/> (Accessed on 1 December 2014)

[92]. GNI. (2014) Available at $<$ http://data.worldbank.org/indicator/NY.GNP.MKTP.CD $>$ (Accessed on 4 December 2014)

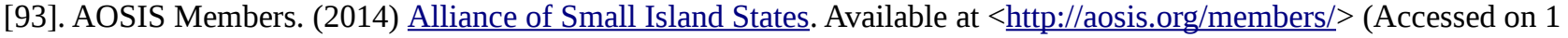
December 2014)

[94]. Vujanić V Dundee LM. CLIMATE CHANGE LITIGATION AND EU ENVIRONMENTAL LIABILITY DIRECTIVE. Collected Papers of the Faculty of Law in Split, vol. 48, no. 1, 2011.

[95]. The World Bank. GNI. Available at<http://data.worldbank.org/indicator/NY.GNP.MKTP.CD> (Accessed on 29 January 2015)

[96]. Coral Davenport. Industry Awakens to Threat of Climate Change. The New York Times. (2014) Available at $<$ http://www.nytimes.com/2014/01/24/science/earth/threat-to-bottom-line-spurs-action-on-climate.html? r=1> (Accessed on 4 December 2014)

[97]. Corporate Europe Observatory. The right to say no: EU-Canada trade agreement threatens fracking bans. 2013. Available at $<$ http://corporateeurope.org/climate-and-energy/2013/05/right-say-no-eu-canada-trade-agreementthreatens-fracking-bans $>$ (Accessed on 29 January 2015)

[98]. BBC News. Philip Momis sues Australia over cigarette packaging. (2011) Available at $<\underline{\text { http://www.bbc.co.uk/news/world-asia- }}$ 15815311> (Accessed on 29 January 2015)

[99]. The Economist. The arbitration game. (2014) Available at < $<$ http://www.economist.com/news/finance-andeconomics/21623756-governments-are-souring-treaties-protect-foreign-investors-arbitration> (Accessed on 29 January 2015)

[100]. Samenow J. The Washington Post. Spring outlook: NOAA warns of unrelenting California drought, Midwest flood risk, and cold in North. (2014) Available at $<\underline{\text { http://www.washingtonpost.com/blogs/capital-weather- }}$ gang/wp/2014/03/20/spring-outlook-noaa-warns-of-unrelenting-california-drought-midwest-flood-risk-and-cold-innorth/> (Accessed on 27 January 2015)

[101]. Schumann R. Major Floods and Droughts in California. (2013) Available at $<$ http://geochange.er.usgs.gov/sw/impacts/hydrology/state fd/cawater1.html > (Accessed on 27 January 2015)

[102]. Environmental Alert. (2010) Global warming litigation: Native Village of Kivalina Available at $<$ http://www.wilsonelser.com/files/repository/EnvTox GlobalWarming Litigation Kivalina AlertJan2010.html $>$ (Accessed on 4 December 2014)

[103]. The United States District Court. (2007) Available at $<$ http://ag.ca.gov/globalwarming/pdf/California GeneralMotors Decision Dismiss 2007Aug17.pdf (Accessed on 11 February 2015)

[104]. Cullen T. The Wall Street Journal. Getting Insurance Isn't Easy For Some Unlucky Homeowners

(2003) Available at <http://www.wsj.com/articles/SB106380332733463200> (Accessed on 31 January 2015)

[105]. Adams M. USA Today. Astorm of trouble (2006) Available at $<$ http://usatoday30.usatoday.com/money/industries/insurance/2006-05-23-hurricane-insurance-usat x.htm > (Accessed on 31 January 2015)

[106]. Stfford RT. FEMA. (2014) Disaster Relief and Emergency Assistance Act, as amended, and Related Authorities as of April 2013. Available at $<$ https://www.fema.gov/media-library/assets/documents/15271?id=3564> (Accessed on 31 January 2015)

[107]. Gillis J. The New York Times. As Coasts Rebuild and U.S. Pays, Repeatedly, the Critics Ask Why. (2012) Available at $<$ http://www.nytimes.com/2012/11/19/science/earth/as-coasts-rebuild-and-us-pays-again-critics-stop-to-askwhy.html?pagewanted $=$ all \& $\mathrm{r}=0>$ (Accessed on 31 January 2015) 
Preprint: Negin Heidari \& Joshua M. Pearce. A Review of Greenhouse Gas Emission Liabilities as the Value of Renewable Energy for Mitigating Lawsuits for Climate Change Related Damages. Renewable and Sustainable Energy Reviews 55C (2016) pp. 899-908. DOI: 10.1016/j.rser.2015.11.025

[108]. Justia US Supreme Court. Friends of Earth, Inc. v. Laidlaw Environmental Services (TOC), Inc. (2010) Available at $<$ https://supreme.justia.com/cases/federal/us/528/167/case.html $>$ (Accessed on 4 December 2014)

[109]. Legal Information Institute. American Electric Power Co. v. Connecticut. (2011) Available at $<$ http://www.law.cornell.edu/supct/cert/10-174> (Accessed on 4 December 2014)

[110]. Oyez. MASSACHUSETTS v. ENVIRONMENTAL PROTECTION AGENCY

Available at <http://www.oyez.org/cases/2000-2009/2006/2006 05 1120/> (Accessed on 4 December 2014)

[111]. The Nature Conservancy. Climate change is already affecting economies around the world.

Available at $<\underline{\text { http://www.nature.org/ourinitiatives/urgentissues/global-warming-climate-change/threats-impacts/economic- }}$ loss-and-damage.xml $>$ (Accessed on 30 January 2015)

[112]. Union of Concerned Scientists. Climate Hot Map. GLOBAL WARMING EFFECTS AROUND THE WORLD Available at $<$ http://www.climatehotmap.org/global-warming-effects/economy.html $>$ (Accessed on 30 January 2015)

[113]. WPF. Climate Change Costs. Available at < http://www.worldpreservationfoundation.org/topic.php? cat=economicCosts\#.VMueoyvF9jc > (Accessed on 30 January 2015)

[114]. Kenny R, Law C, Pearce JM. Towards real energy economics: energy policy driven by life-cycle carbon emission. Energy Policy, 2010;38(4), 1969-1978.

[115]. Kessides IN, Wade DC Towards a sustainable global energy supply infrastructure: Net energy balance and density considerations. Energy Policy. 2011;39(9), 5322-5334.

[116] Pearce JM. Photovoltaics—a path to sustainable futures. Futures 2002; 34(7), 663-674.

[117] Panwar NL, Kaushik SC, Kothari S. Role of renewable energy sources in environmental protection: a review. Renewable and Sustainable Energy Reviews. 2011; 15(3), 1513-1524.

[118] Alafita T, Pearce JM. Securitization of residential solar photovoltaic assets: Costs, risks and uncertainty, Energy Policy. 2014; 67, 488-498.

[119]. Acquaye A, Duffy A, Basu B. Embodied emissions abatement-A policy assessment using stochastic analysis. Energy Policy. 2011;39(1), 429-441.

[120]. Ekundayo D, Perera S, Udeaja C, Zhou L. Carbon review and qualitative comparison of selected carbon counting tools. In RICS COBRA Research Conference, Las Vegas, Nevada USA. 2012. 